\title{
Evaluasi Pencapaian Program Keluarga Berencana di Puskesmas Kota Bukittinggi Tahun 2019
}

\author{
Widya Nengsih ${ }^{1}$,Adis Fitriyana ${ }^{2}$ \\ Program Studi Kebidanan Universitas Fort de Kock Bukittinggi \\ Email :Widyanengsih1612@gmail.com
}

Submitted : 24-04-2020, Reviewer:26-04-2020, Accepted: 30-04-2020

\begin{abstract}
Family planning is an action that helps couples to avoid unwanted pregnancies, get births, and determine the number of children in the family. It is known that the achievement of contraceptive use in the City of Bukittinggi has a number of productive couple as many as 24,563 people, and the number of active family planningwas $13,781(56.11 \%)$. The research objective is to evaluate the achievement of family planning programs in the City Health Center in Bukittinggi year 2018. This research was a qualitative research with evaluation study method. This research was conducted at the Health Center ofBukittinggi Cityon July $5^{\text {th }}$ - August $15^{\text {th }} 2018$. The informants consisted of 4 heads of Health Center, 4 midwives holding a family planning program, and 8 users of family planning services. Data collection using in-depth interviews, then processed with the Miles and Huberman models. The results of the study revealed that there was enough quality of Human Resources in the implementation of family planning, and that adequate funds and facilities and infrastructure were sufficient. Inhibiting factors / constraints include lack of involvement of cadres, lack of support in using family planning, especially from husbands, and location of the Helath Center that are less strategic and difficult to reach the community. The expected output has not reached the target, in accordance with the findings in the field.
\end{abstract}

Keywords : Achievement of Family Planning Program

\begin{abstract}
Abstrak
Keluarga berencana adalah tindakan yang membantu pasangan suami istri untuk menghindari kehamilan yang tidak diinginkan, mendapatkan kelahiran, serta menentukan jumlah anak dalam keluarga. Diketahui pencapaian penggunaan kontrasepsi KB di Kota Bukittinggi terdapat jumlah PUS sebanyak 24.563 orang, dan jumlah Kb aktif 13.781 (56,11\%). Tujuan penelitian untuk mengevaluasi pencapaian program KB di Puskesmas Kota Bukittinggi tahun 2019 Penelitian ini adalah penelitian kualitatif dengan metode evaluasi study. Penelitian ini di lakukan di puskesmas Kota Bukittinggi pada tanggal 5 juli - 15 Agustus 2019. Informan terdiri dari 4 orang kepala Puskesmas, 4 orang bidan pemegang program $\mathrm{KB}$, dan 8 orang pengguna pelayanan KB. Pengumpulan data dengan menggunakan wawancara mendalam, kemudian diolah dengan model Miles dan Huberman. Hasil penelitian diketahui bahwa sudah cukup kualitas Sumber Daya Manusia dalam pelaksanaan KB,dan dana yang sudah memadai serta sarana dan prasarana sudah cukup memadai. Faktor penghambat/kendala diantaranya kurangnya keterlibatan kader, kurangnya dukungan dalam menggunakan KB terutama dari suami, dan lokasi puskesmas yang kurang strategis dan susah di jangkau masyarakat.
\end{abstract}

Kata Kunci : Pencapaian Program KB 


\section{PENDAHULUAN}

A.

\section{Latar Belakang}

Tujuan keluarga berencana nasionalmeningkatkan kesejahteraan ibu, anak dalam rangka mewujudkan NKKBS yang menjadi dasar terwujudnya masyarakat yang sejahtera dengan mengendalikan kelahiran sekaligus menjamin terkendalinya pertambahan penduduk, Meningkatkan jumlah penduduk untuk menggunakan alat kontrasepsi, Menurunnya jumlah angka kelahiran bayi, Meningkatnya kesehatan keluarga berencana dengan cara penjarangan kelahiran. (Pinem,2014)

Salah satu upaya yang dilakukan dalam mensukseskan program keluarga berencana tersebut adalah dengan memberikan pelayananyang bermutu dan sesuai dengan kebutuhan. Tentunya tersebut menuntun tenaga kesehatan untuk dapat memberikan pelayanan dengan standar yang telah ditetapkan. Kompetensi tenaga kesehatan sangat dituntut dalam setiap pelayanan yang diberikan ( Handayani, 2010)

Ada beberapa metode atau alat kontrasepsi yang bisa digunakan, bagi wanita dan pria antara lain pil $\mathrm{KB}$, susuk atau implant, alat kontrasepsi dalam rahim (AKDR) dan medis operasi wanita
(MOW) biasa disebut tubektomi sedangkan bagi pria biasanya dengan cara pantang berkala, senggama terputus, kondom dan medis operasi pria (MOP) atau vasektomi. Pilihan kontrasepsi yang tersedia bagi pria terbatas dibandingkan dengan yang tersedia bagi perempuan. Sebagian besar penelitian telah ditujukan pada klien dimana wanita lebih mudah menghentikan ovulasi bulanan daripada pria dimana proses sperma yang terus menerus (Everent, 2012)

\section{METODOLOGI PENELITIAN}

\section{Tempat dan waktu penelitian}

Penelitian telah dilakukan pada bulan Juli - Agustus 2019 di Puskesmas Kota Bukittinggi

\section{Jenis Penelitian}

Jenis penelitian ini kualitatif dengan metode evaluasi studyyaitu penelitian untuk menilai suatu program/pencapaian yang sedang atau peningkatan program tersebut. Teknik penentuan informan yang peneliti gunakan adalah teknik purpose sampling yaitu teknik penentuan sampel sumber data dengan pertimbangan tertentu (sugiyono, 2010)

\section{Informan Penelitian}

Informan dalam penelitian ini adalah 4 kepala puskesmas, 4 bidan 
pemegang program $\mathrm{KB}$, dan 8 pengguna pelayanan $\mathrm{KB}$ yang dirinci pada masingmasing lingkungan sebagai berikut :

Informan pada penelitian ini adalah :

Puskesmas Mandiangin: 4 orang

Puskesmas Tigo Baleh : 4 orang

Puskesmas Gulai Bancah: 4orang

Puskesmas Mandiangin Plus : 4orang

\section{Pengumpulan Data}

Wawancara yaitu pengumpulan data dengan menggali data secara luas namun mengarah pada masalah tertentu secara detail. Peneliti menggunakan daftar pertanyaan yang sudah menjurus ke tujuan penelitian, dan mendorong partisipan mengekspresikan pandangan secara panjang lebar

\section{Analisa Data}

langkah-langkahnya yaitu mulai dari tahap pertama reduksi data, tahap kedua display/penyajian data, dan tahap ketiga dengan pengambilan kesimpulan lain diverifikasi. Ketiga tahapan tersebut berlangsung secara stimulan atau merupakan siklus yang interaktif

\section{HASIL DAN PEMBAHASAN}

\section{Komponen input}

\section{a. SDM}

Dari hasil penelitian Di Puskesmas Kota Bukittinggi untuk sumber daya manusia kualifikasi pendidikan untuk tenaga bidan rata- rata diploma tiga (D3) dan sudah sesuai dengan peraturan mentri kesehatan RI (Permenkes) tapiselama ini tidak ada kendala atau masalah, dan memberikan pelayanan cukup baik dibuktikan dengan kepuasan dari masyarakat terhadap pelayanan yang diberikan oleh para tenaga kesehatan (bidan). berdasarkan permenkes 75 tahun 2014 standar ketenagaan merupakan kondisi minimal yang diharapkan agar puskesmas dapat terselelnggara dengan baik. Dan kualifikasi pendidikan sumber daya manusia untuk pengelola program keluarga berencana di puskesmas sudah sesuai atau mengacu pada peraturan menteri kesehatan bahwa bidan dengan berpendidikan diploma III sejak tahun 2000, sehingga dengan keilmuan yang dimiliki oleh bidan mampu memberikan pelayanan program keluarga berencana kepada masyarakat mampu mencapai program sesuai dengan target, kepuasan masyarakat terhadap pelayanan $\mathrm{KB}$ yang diberikan masyarakat merasa puas sebab bidan (sumber daya manusia) sudah berkompeten. Serta meningkatkan pelatihan untuk menambah ilmu terbaru.

\section{b. Dana}

Di Puskesmas Kota Bukittinggi sumber dana di dapat dari pemerintah daerah (DAK) dan BKKBN tetapi tergantung kepada pemegang program KB untuk lebih bijak dalam mengelola 
dana untuk setiap kegiatan. sumber pendanaan untuk kegiatan pelaksanaan program KB di puskesmas sudah sesuai dengan undang- undang No. 23 tahun 2014

\section{c. Sarana dan prasarana}

sarana dan prasarana sudah memadai dan tidak menjadi masalah dalam melakukan dalam pelayanan KB kepada masyarakat. Hal ini sama dengan pernyataan dari pengguna pelayanan $t$ entang alat-alat yang digunakan dalam pelayanan cukup memadai. sesuai dengan peraturan pemerintah seperti masih kurang lengkapnya peralat artinya belum sesuai dengan peraturan pemerintah tentang ketersediaan sarana dan prasarana, namum petugas pelaksana program KB masih bisa melakukan pelayanan kepada sasaran sarana seadanya, sebenarnya kondisi seperti ini tidak bisa dibiarkan pihak puskemas, harus ada daftar list segala kebutuhan pelaksanaan program KB yang terstandarisasi sesuai dengan PP No. 87 tahun 2014.

\section{Komponen proses}

\section{a. Pelaksanaan}

berdasarkan hasil wawancara kepada informan Pelaksanaan KB 2 dari 4 Puskesmasmengatakan pelaksanaan program KB sudah sesuai dengan SOP dan sarana yang ada di Puskesmas tanpa kendala untuk pelaksanaan program $\mathrm{KB}$.
Peraturan pemerintah dalam pelayanan KB yang diberikan sudah berjalan dengan baik dan tepat sasaran yaitu untuk PUS dan Akseptor yang ingin ikut KB, karena semua PUS atau peserta KB yang ingin ikut KB mereka langsung datang ke Puskesmas untuk menggunakan alat kontrasepsi

\section{b. Pengawasan}

Pengawasan dilakukan oleh internal puskesmas atau supervisi kepada program KB, Dinas Kesehatan Kota Bukittinggi bersama pihak BKKBN yang selalu melakukan Monitoring dan evaluasi terhadap kegiatan Program KB serta kecukupan alat kontrasepsi. BKKBN melakukan pengawasan terhadap peserta KB safari, yang meliputi obat dan Alat Kontrasepsi

\section{c. Pencatatan}

semua Puskesmas di kota Bukittinggi melakukan pencatatan KB secara rutin setelah melakukan pelayanan KB dan ada pengarsipan, bahwa semua pengguna pelayanan memiliki pencatatan. sistem pencatatan secara rutin dari setiap kegiatan $\mathrm{KB}$ dibuku kegiatan $\mathrm{KB}$, dan adanya kartu kepesertaan yang diberikan kepada Akseptor, Sistem pencatatan untuk kegiatan Program KB selalu dilakukan sebagai bukti kegiatan KB sudah dilakukan dan dilakukan secara rutin mulai 
dari pengunaan obat oleh akseptor $\mathrm{KB}$, dan jumlah kepesertaan KB.

\section{d. Pelaporan}

puskesmas untuk Pelaporannya sudah bagus secara rutin dan terhadap pencapaiannya, Sistem Pelaporan yang dilakukan oleh pihak puskesmas sudah secara rutin dilakukan pada setiap kegiatan Program KB , yang dilaporkan secara berkala ke dinas kesehatan dan BKKBN dari laporan ada evaluasi tentang tingkat keberhasilan program KB di puskesmas Kota Bukittinggi

\section{komponen output}

\section{a. Pencapaian}

Pencapaian Program KB diharapkan sesuai dengan target yang telah ditetapkan dari pihak Dinas kesehatan dan BKKBN, artinya jumlah akseptor KB yang baru akan bertambah dan yang lama tetap ikut menjadi peserta Program KB. Namun ada kendala dalam mencapai program KB antara lain masih tingginya keinginan PUS untuk memiliki anak kembali. PUS ada yang program hamil jadi out put dari pencapain program $\mathrm{KB}$ dan mampu memenuhi Target yang ditetapkan

\section{b. Kendala}

$$
\text { dalam pencapaian cakupan }
$$
program KB, kurangnya keterlibatan kader serta kurang kesadaran atau kurangnya pengetahuan masyarakat khususnya suami, kendala kurangnya kesadaran masyarakat tentang Program KB, walaupun penyuluhan Program KB dan efek samping yang mereka rasakan setelah menggunakan $\mathrm{KB}$, belum lagi suami tidak mengizinkan untuk menggunakan KB.

\section{c. Solusi}

program KB selalu memberikan penyuluhan tentang Program KB dan memfasiltasi Masyarakat yang akan ikut menjadi Akseptor KB terutama PUS di usia Produktif yang telah mempunyai anak lebih dari 2 orang serta menjelaskan tentang manfaat ikut program KB. Untuk mengatasi efek samping dari pengunaan alat kontrasepsidan dilakukan pada perorangan atau kelompok, serta ada safari $\mathrm{KB}$

\section{Kesimpulan}

\section{Komponen Input}

\section{a. Sumber Daya Manusia}

Di Puskesmas Kota Bukittinggiuntuk SDM sudah sesuai standar dari kualifikasi pendidikan semua sudah berpendidikan minimal Diploma Tiga ( DIII) Kebidanan jadi sudah sesuai dengan Permenkes no. 369 tahun 2017 dalam pelaksanaan program $\mathrm{KB}$.

\section{b. Dana}

Di Puskesmas untuk sumber dana sesuai dengan Undang - undang no. 23 tahun 2014 bahwa bersumber dari APBD dan BKKBN yang di kelola langsung 
oleh pemegang Program KB di

Puskesmas.

\section{c. SaranadanPrasarana}

Di Puskesmas untuk sarana dan prasarana sudah mencukupi hanya saja belum sesuai standar untuk pelaksanaan program pelaksanaan KB yaitu PP No. 87 tahun 2014.

\section{Komponen Proses}

Pada proses pelaksanaan program KB pada proses pelaksanaan sudah dilakukan dengan baik sesuai dengan SOP dan Peraturan Pemerintah.

\section{a. Pelaksanaan}

Dalam pelaksanaan program KB mengacu kepada SOP yaitu PP No. 87 tahun 2014.

\section{b. Pengawasan}

Untuk pengawasan program KB dilakukan secara internal oleh pihak puskesmas sendiri dan eksternal dari Dinas Kesehatan dan BKKBN secara berkala.

\section{c. Pencatatan}

Untuk sistem pencatatan secara rutin dilakukan setelah pelaksanaan kegiatan program KB oleh pemegang program $\mathrm{KB}$ dan diarsipkan.

\section{d. Pelaporan}

Sistem pelaporan dilakukan secara berkala kepada Dinas kesehatan dan BKKBN tentang pelaksanaan program $\mathrm{KB}$ dan alat kontrasepsi yang dibutuhkan.

\section{Komponen Output}

Luaran yang diharapkan oleh Puskesmas dari pelaksanaan Program $\mathrm{KB}$ :

\section{a. Pencapaian}

Untuk pencapaian pelaksanaan program KB belum sesuai dengan target yang ditetapkan oleh Dinas Kesehatan dan BKKBN. Namun dinas kesehatan berharap $70 \%$ dari target akan tercapai artinya PUS untuk ikut menjadi Akseptor KB.

b. Kendala

Kurangnya keterlibatan kader, serta kesadaran masyarakat untuk ikut Program KB masih adanya keingin masyarakat mempunyai anak lagi walaupun sudah mempunyai anak lebih dari 2 orang dan ditambah lagi minimnya dukungan dari keluarga atau suami.

c. Solusi

$$
\text { Petugas program KB }
$$
puskesmas selalu memberikan informasi melalui penyuluhan dan KIE kepada Masyarakat tentang program $\quad \mathrm{KB} \quad$ secara berkesinambungan, yang bertujuan untuk meningkatkan kesadaran masyarakat untuk ikut menjadi 
Akseptor KB terutama PUS usia Produktif

\section{UCAPAN TERIMAKASIH}

Alhamdulillah puji syukur kepada Allah SWT, karena kehendak dan ridhaNya peneliti dapat menyelesaikan Penelitian ini. Peneliti sadari penelitian ini tidak akan selesai tanpa doa, dukungan, bimbingan dan dorongan dari berbagai pihak.

\section{REFERENSI}

Abu Bakar, 2014. Kesehatan Reproduksi Dan Keluarga Berencana Dalam Tanya Jawab. Jakarta : Rajagrafindo Persada

Affandi, 2014. Buku Panduan Praktis Pelayanan Kontrasepsi. Jakarta : PT bina Pustaka Sarwono Prawiroharjo

Asnawi, 2008. Manajemen program keluarga berencana di kota Gorontalo.

Azwar, 2010. Pengantar Administrasi Kesehatan. Tangerang : Binarupa Aksara

BKKBN.2017. Review Program KKBPK. Sumatera Barat
Bungin, 2011. Metodologi Penelitian Kualitatif. Jakarta : Rajagrafindo Persada

Glasier, A. \& Gabbie, A. 2004. Keluarga Berencana Dan Kesehatan Reproduksi, Jakarta:EGC

Hartanto, 2010. Keluarga Berencana dan Kontrasepsi. Jakarta : Pustaka Sinar Harapan

Kepmenkes RI. 2014. Pedoman manajemen pelayanan keluarga berencana

Kurniati dan Effendin. 2012. Kajian SDM Kesehatan di Indonesia. jakarta selatan: Salemba Medika

Manuaba,2002.MemahamiKesehatanRepr oduksiWanita.Jakarta :Arcan

Maziyyah. 2015. Evaluasi input program KB MKJP di kabupaten magelang

Menkes RI.2013. Situasi keluarga berencana di Indonesia.

Notoatmodjo, S. 2003. Metodologi Penelitian Kesehatan. Jakarta. Rineka Cipta

Permenkes RI nomor 87. 2014. Tentang perkembangan kependudukan dan pembangunan keluarga, 
keluarga berencana, dan sistem informasi keluarga.

Permenkes RI nomor 39.2016. pedoman penyelenggaraan program indonesia sehat dengan pendekatan keluarga

Permenkes RI nomor 66. 2017.Petunjuk operasional penggunaan dana alokasi khusus fisik bidang kesehatan tahun anggaran 2018

Permenkes RI nomor 82. 2015. Petunjuk teknis penggunaan dana alokasi khususBidang kesehatan, serta sarana dan prasaranaPenunjang subbidang sarpras kesehatan tahun anggaran 2016

Pinem, 2014. Kesehatan Reproduksi Dan Kontrasepsi. Jakarta : KDT

Profil Dinas Kesehatan Indonesia, 2016

Profil Dinas Kesehatan Provinsi Sumatra Barat, 2016

Profil Dinas Kesehatan Kota Bukittinggi, 2017

Saifuddin, 2010. Buku Panduan Praktis Pelayanan Kontrasepsi. Jakarta : PT bina Pustaka Sarwono Prawiroharjo
Sastroasmoro, 2012. Dasar-Dasar Metodologi Klinis. Jakarta : Sagung Seto

Suarli \& bachtiar. 2010. Manajemen Keperawatan dengan pendekatan praktis. Jakarta, Erlangga.

Sugiyono. 2009. Metode Penelitian Kuantitatif, Kualitatif dan $R \& D$. Bandung : Alfabeta

Sulistyawati, 2012. Pelayanan Keluarga Berencana. Jakarta selatan : Salemba Medika

Suratun, 2013. Pelayanan Keluarga Berencana dan Pelayanan Kontrasepsi. Jakarta : KDT

Swarjana, 2016. Keperawatan Kesehatan Komunitas. Yogyakarta : ANDI 